\title{
Hepatitis Induced by Noni Juice from Morinda citrifolia: A Rare Cause of Hepatotoxicity or the Tip of the Iceberg?
}

\author{
B. Yüce ${ }^{a} \quad$ V. Gülberg ${ }^{a} \quad$ J. Diebold ${ }^{b}$ A.L. Gerbes ${ }^{a}$

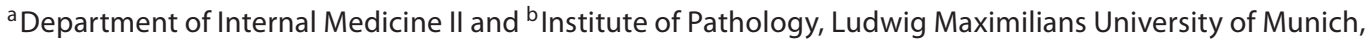 \\ Munich, Germany
}

\section{Key Words}

Herbal toxicity · Acute hepatitis · Complementary

medicine $\cdot$ Dietary supplement

\begin{abstract}
A 24-year-old female patient presented to her community hospital with mild elevations of serum transaminase and bilirubin levels. Because of multiple sclerosis, she was treated with interferon beta-1a for 6 weeks. After exclusion of viral hepatitis due to hepatitis $A-E$, interferon beta-1a was withdrawn under the suspicion of drug-induced hepatitis. One week later, she was admitted again to her community hospital with severe icterus. The transaminase and bilirubin levels were highly elevated, and a beginning impairment of the liver synthesis was expressed by a reduced prothrombin time. The confinement to our department occurred with a fulminant hepatitis and the suspicion of beginning acute liver failure. There was no evidence for hepatitis due to potentially hepatotoxic viruses, alcoholic hepatitis, Budd-Chiari syndrome, hemochromatosis, and Wilson's disease. In her serum there were high titers of liver-kidney microsomal type 1 autoantibody; the serum gamma globulin levels were in the normal range. Fine-needle aspiration biopsy of the liver ruled out an autoimmune hepatitis but showed signs of drug-induced toxicity. During the interview, she admitted
\end{abstract}

that for 'general immune system stimulation' she had been drinking Noni juice, a Polynesian herbal remedy made from a tropical fruit (Morinda citrifolia), during the past 4 weeks. After cessation of the Noni juice ingestion, her transaminase levels normalized quickly and were in the normal range within 1 month.

Copyright $\odot 2006$ S. Karger AG, Basel

\section{Introduction}

The use of complementary and alternative medicine, in particular herbal products and dietary supplements, is rapidly growing in Europe and in the United States [1]. Since such products are usually labeled as dietary supplements, only minor requirements for consumer's safety are required before entering the market.

Noni juice, a dietary supplement, is an increasingly popular herbal drink which is currently distributed by several companies worldwide. One of those companies has been noted as 'one of the fastest-growing private companies in America and less than ten private companies in the history of the world were able to equal this company's first six years of growth' [http://www.tahitiannoni.com/ united_states/english/public/company]. This suggests increasing consumption of Noni juice in the near future.

\section{KARGER}

Fax +4161306 1234 E-Mail karger@karger.ch www.karger.com
(C) 2006 S. Karger AG, Basel

0012-2823/06/0733-0167\$23.50/0

Accessible online at:

www.karger.com/dig
Veit Gülberg, MD

Department of Internal Medicine II, Ludwig Maximilians University of Munich

Marchioninistrasse 15

DE-81377 München (Germany)

Tel. +49897095 0, Fax +49897095 5284, E-Mail veit.guelberg@med.uni-muenchen.de 


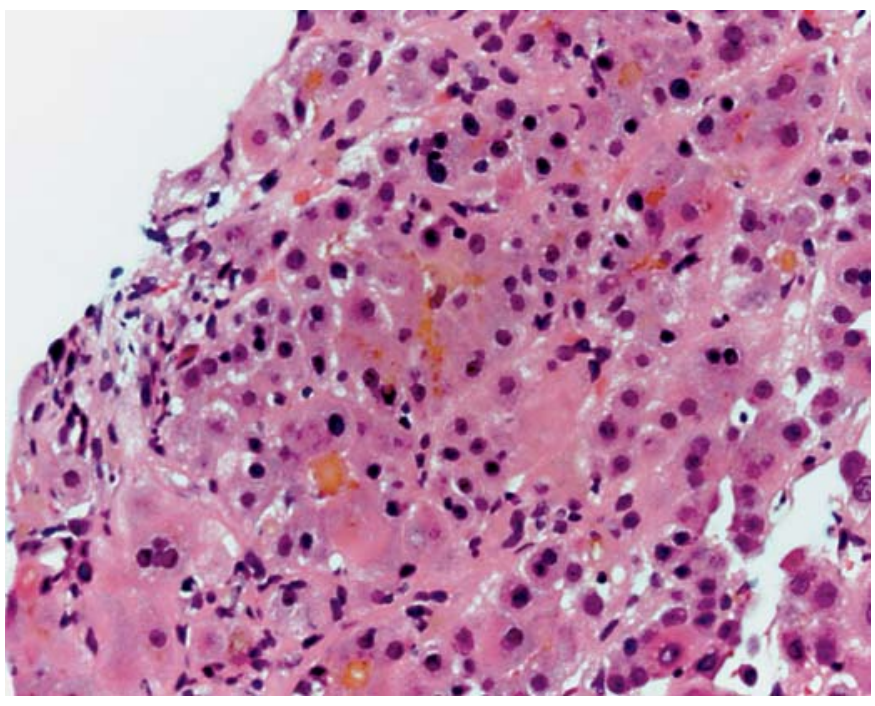

Fig. 1. Representative liver biopsy specimen, revealing periportal and intralobular hepatocyte necrosis, mixed inflammatory reaction, and prominent canalicular cholestasis. HE. $\times 400$.

The Noni fruit was introduced in the Pacific area nearly 2,000 years ago and is one of the most commonly used and appreciated remedies in local traditional medicine for a variety of disorders [2]. Apart from scanty preclinical data, efficacy and safety of Noni juice were not validated in controlled clinical trials. Here, we report a patient presenting with subacute liver failure most likely related to the ingestion of high amounts of Noni juice.

\section{Case Report}

A 24-year-old female patient presented to her community hospital with jaundice. On admission the alanine aminotransferase level was elevated to $1,538 \mathrm{U} / \mathrm{l}$, that of bilirubin to $5.25 \mathrm{mg} / 100 \mathrm{ml}$, and that of $\gamma$-glutamyltransferase to $110 \mathrm{U} / \mathrm{l}$. After ruling out viral hepatitis A-E by serological testing, there was a suspicion of druginduced hepatitis due to interferon beta-1a (IFN). The patient had been treated with IFN for 10 weeks after the diagnosis of multiple sclerosis had been established, following an episode of inflammation of the optic nerve. After 4 weeks of IFN therapy, a routine laboratory examination revealed normal liver enzyme values. Nevertheless, IFN was initially suspected of causing her hepatitis and was, therefore, withdrawn.

One week after IFN withdrawal, the patient was examined again, with a dramatic increase of her liver enzyme levels (bilirubin $43.5 \mathrm{mg} / 100 \mathrm{ml}$, aspartate aminotransferase 2,818 U/l, alanine aminotransferase $3,648 \mathrm{U} / \mathrm{l}$ ). Thus, she was referred to our tertiary liver unit with the diagnosis of subacute liver failure.

Physical examination revealed a patient with severe jaundice; apart from this, the physical examination was inconspicuous. An ultrasound scan of the liver ruled out intra- or extrahepatic bile duct obstruction as well as vascular abnormalities or focal lesions.

We found no evidence for viral hepatitis A-E or other potentially hepatotoxic viruses, alcoholic hepatitis, Budd-Chiari syndrome, hemochromatosis, or Wilson's disease. The most remarkable laboratory finding was an increased titer for liver-kidney microsomal autoantibody type $1(1: 3,840)$, with no other autoantibodies detectable. However, liver biopsy did not reveal evidence for an autoimmune disease. There were confluent necroses of periportal and intralobular hepatocytes, lymphoplasmacellular and neutrophil inflammation, canalicular cholestasis, and moderate fibrosis (fig. 1). This pattern was highly suspicious for druginduced hepatitis. Furthermore, the autoimmune hepatitis score [3] including histology summed up to 5 points, rating the diagnosis of autoimmune hepatitis as unlikely.

At this point, we took an extended medical history and asked the patient about any recent changes of her dietary habits in detail. Now she reported that she had been drinking Noni juice for 4 weeks for 'general immunostimulation'. We convinced the patient to immediately stop the consumption of Noni juice. Thereafter, the transaminase levels fell rapidly and were within the normal range after 1 month (fig. 2). In summary, we diagnosed a druginduced hepatitis due to ingestion of Noni juice.

\section{Discussion}

Hepatotoxicity due to herbal remedies is a rare, but well-known adverse event [4]. Since most of these herbal remedies are dietary supplements, only few requirements are necessary to launch such products onto the market. Scarcely a complete analysis of all ingredients is available, and a definitive characterization of pharmacologically active as well as toxic compounds is difficult or even impossible. Due to nonstandardized manufacturing procedures and naturally occurring variability, the composition of compounds varies in most of the preparations. These issues also apply to Noni juice. A number of compounds was identified, two of them having the potential for being hepatotoxic [2], but a complete analysis is lacking. The first group comprises the anthraquinones (like nordamnacanthal, morindone, rubiadin, rubiadin-1methyl ether, anthraquinone glycoside) which are candidates for having a dose-dependent hepatotoxicity. The second group which was suspected also for having idiosyncratic hepatotoxic potential are the coumarins, e.g., scopoletin [2]. Very recently, 3 cases of severe hepatitis were reported demonstrating potential hepatotoxicity of Noni juice $[5,6]$ (table 1). Since there are millions of Noni juice consumers, idiosyncratic hepatotoxicity seems more likely to be the problem. Moreover, the high titers of autoantibodies of the liver-kidney microsomal type in our patient may be a clue to this type of drug reaction, since 
Fig. 2. Serum concentrations of alanine aminotransferase $(\mathrm{U} / \mathrm{l} ; \mathbf{O})$ and bilirubin $(\mathrm{mg} / 100 \mathrm{ml} ; \boldsymbol{\nabla})$ during and after cessation of the IFN therapy and ingestion of Noni juice.

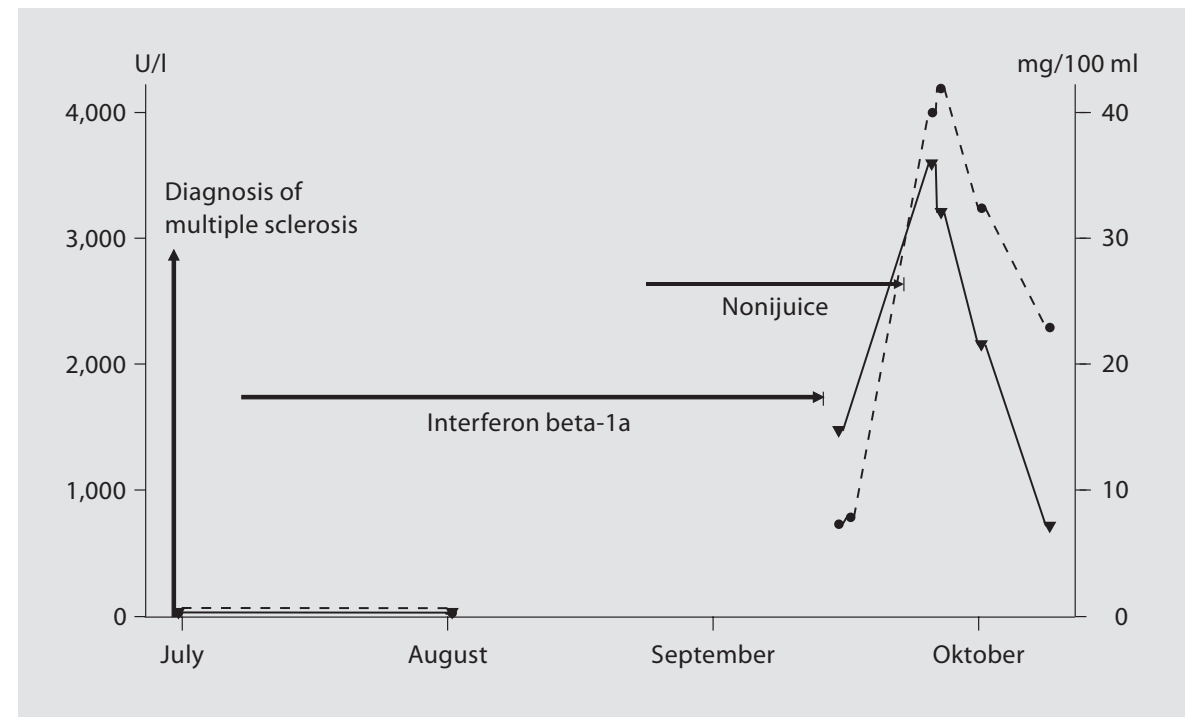

Table 1. Reports on the hepatotoxicity of Noni juice

\begin{tabular}{|c|c|c|c|c|c|c|c|}
\hline Gender & $\begin{array}{l}\text { Age } \\
\text { years }\end{array}$ & $\begin{array}{l}\text { Concomitant } \\
\text { medication }\end{array}$ & Amount of Noni & $\begin{array}{l}\text { Duration of } \\
\text { ingestion }\end{array}$ & $\begin{array}{l}\text { Delay between } \\
\text { ingestion and } \\
\text { onset of symptoms }\end{array}$ & $\begin{array}{l}\text { Laboratory values } \\
\text { (maximum noted) }\end{array}$ & $\begin{array}{l}\text { Refer- } \\
\text { ence }\end{array}$ \\
\hline Male & 45 & none & 1 glass/day & 'few weeks' & 'few weeks' & $\begin{array}{l}\text { AST } 604 \mathrm{U} / 1 \\
\text { ALT } 1,995 \mathrm{U} / 1 \\
\text { GGT } 539 \mathrm{U} / 1 \\
\text { bilirubin } 0.82 \mathrm{mg} / \mathrm{dl}\end{array}$ & 6 \\
\hline Male & 29 & $\begin{array}{l}\text { acetaminophen, } \\
\text { Chinese herbal } \\
\text { mix }\end{array}$ & $\begin{array}{l}1.5 \text { liters within } \\
3 \text { weeks prior to } \\
\text { admission }\end{array}$ & not stated & not stated & $\begin{array}{l}\text { AST } 1,557 \mathrm{U} / 1 \\
\text { ALT } 626 \mathrm{U} / \mathrm{l} \\
\text { bilirubin } 45.3 \mathrm{mg} / \mathrm{dl}\end{array}$ & 5 \\
\hline Female & 62 & none & 2 liters & 4 months & 4 weeks & $\begin{array}{l}\text { AST 1,455 U/l } \\
\text { ALT 2,381 U/1 } \\
\text { GGT } 241 \mathrm{U} / 1 \\
\text { bilirubin } 2.9 \mathrm{mg} / \mathrm{dl}\end{array}$ & 5 \\
\hline Female & 24 & interferon beta-1a & $1-1.5$ liters & 4 weeks & 3 weeks & $\begin{array}{l}\text { AST 2,818 U/1 } \\
\text { ALT 3,648 U/l } \\
\text { bilirubin } 43.5 \mathrm{mg} / 100 \mathrm{ml}\end{array}$ & $\begin{array}{l}\text { this } \\
\text { study }\end{array}$ \\
\hline
\end{tabular}

AST $=$ Aspartate aminotransferase; ALT $=$ alanine aminotransferase; GGT $=\gamma$-glutamyltransferase .

autoantibodies were reported in hepatotoxicity induced by other drugs [7]. We, therefore, conclude that in our patient Noni juice induced an idiosyncratic hepatitis.

Interactions between other herbal products and synthetic drugs are well known. For example, St. John's wort (Hypericum perforatum) interacts with numerous conventional drugs, including ciclosporin, simvastatin, and others [8]. Thus, it seems quite possible that Noni juice worsened a preexisting liver damage due to IFN; hepatotoxicity of IFN treatment has been reported before in a patient with multiple sclerosis [9]. In another report [3], a preexisting liver damage, possibly due to Chinese herbal mix and acetaminophen, was worsened after the ingestion of Noni juice. Thus, in addition to the potential of damaging a healthy liver, synergistic mechanisms of hepatotoxicity due to Noni juice are likely. 
In summary, the increasing popularity of Noni juice adds another task to gastroenterologists and hepatologists: patients with unexplained elevation of liver enzyme levels or liver failure should be questioned carefully about the ingestion of Noni juice as well as other herbal reme- dies, and patients with preexisting liver impairment should be advised not to consume Noni juice. Quite likely with a growing awareness, the number of patients with diagnosed liver injury due to ingestion of Noni juice will increase.

\section{References}

1 Stickel F, Patsenker E, Schuppan D: Herbal hepatotoxicity. J Hepatol 2005;43:901-910.

2 Wang MY, West BJ, Jensen CJ, Nowicki D, Su C, Palu AK, Anderson G: Morinda citrifolia (Noni): a literature review and recent advances in Noni research. Acta Pharmacol Sin 2002;23:1127-1141

3 Alvarez F, Berg PA, Bianchi FB, et al: International Autoimmune Hepatitis Group Report: review of criteria for diagnosis of autoimmune hepatitis. J Hepatol 1999;31: 929-938.
4 Pageaux GP, Larrey D: Alternative medicine, vitamins, and natural hepatotoxins; in Kaplowitz N, DeLeve LD (eds): Drug-Induced Liver Disease. New York, Marcel Dekker, 2003, pp 709-724.

5 Stadlbauer V, Fickert P, Lackner C, Schmerlaib J, Krisper P, Trauner M, Stauber RE: Hepatotoxicity of Noni juice: report of two cases. World J Gastroenterol 2005;11:47584760.

6 Millonig G, Stadlmann S, Vogel W: Herbal hepatotoxicity: acute hepatitis caused by a Noni preparation (Morinda citrifolia). Eur J Gastroenterol Hepatol 2005;17:444-447.
7 Hinrichsen H, Lüttges J, Klöppel G, Fölsch UR, Schmidt WE: Idiosyncratic drug allergic phenprocoumon-induced hepatitis with subacute liver failure initially misdiagnosed as autoimmune hepatitis. Scand J Gastroenterol. 2001;36:780-783.

8 Stedman C: Herbal hepatotoxicity. Semin Liver Dis 2002;22:195-206.

9 Tremlett HL, Oger J: Elevated aminotransferases during treatment with interferonbeta for multiple sclerosis: actions and outcomes. Mult Scler 2004;10:298-301. 